\title{
PENGEMBANGAN INSTRUMEN PENILAIAN PRAKTIKUM IPA BERBASIS INKUIRI TERBIMBING
}

\author{
M.R. Depiani, N.M. Pujani, N.L.P. Latria Devi \\ Program Studi S1 Pendidikan IPA \\ Universitas Pendidikan Ganesha \\ Singaraja, Indonesia \\ e-mail: \{made.riska.depiani, made.pujani, latria.devi\}@undiksha.ac.id\}
}

\begin{abstract}
Abstrak
Penelitian menggunakan Research and Development ( $R$ \& $D)$ ini dilakukan untuk menghasilkan instrumen penilaian praktikum IPA berbasis inkuiri terbimbing. Penelitian ini mengadopsi model 4D yaitu Define, Design, Develop, dan Disseminate. Pengembangan instrumen pada penelitian ini dibatasi sampai tahap develop, yaitu uji keterbacaan. Penyusunan instrumen penilaian diawali dengan analisis kebutuhan melalui wawancara guru dan siswa. Pada tahap pengembangannya dilakukan uji kevalidan dan uji keterbacaan. Kevalidan instrumen penilaian diuji oleh dua ahli. Keterbacaan instrumen penilaian praktikum IPA berbasis inkuiri terbimbing didapatkan melalui angket uji keterbacaan. Kevalidan dan keterbacaan instrumen penilaian tersebut dianalisis secara deskriptif. Hasil penelitian menemukan: 1) skor rata-rata uji validitas instrumen penilaian praktikum IPA berbasis inkuiri terbimbing dan LKS secara berturut-turut sebesar 3,45 dan 3,62 . Hasil validitas yang diperoleh menyatakan bahwa instrumen penilaian secara keseluruhan termasuk dalam kriteria sangat valid. 2) skor rata-rata uji keterbacaan instrumen sebesar 4,68 dengan kriteria sangat jelas/mudah dipahami. Berdasarkan hasil uji validitas dan uji keterbacaan dapat disimpulkan bahwa instrumen penilaian praktikum IPA berbasis inkuiri terbimbing valid dan terbaca.
\end{abstract}

Kata kunci: instrumen penilaian, praktikum IPA, inkuiri terbimbing

\begin{abstract}
The research using Research and Development (R \& D) was conducted to produce an assessment instrument for guided inquiry-based Natural Sciences. This study adopted the 4D model namely Define, Design, Develop, and Disseminate. The development of instruments in this study was limited to the develop phase, namely the readability test. The preparation of the assessment instruments begins with a needs analysis through teacher and student interviews. During the development phase validity and readability tests are carried out. The validity of the assessment instrument was tested by two experts. The reading of the guided inquiry IPA practicum assessment instrument was obtained through a readability test questionnaire. The validity and legibility of the assessment instruments were analyzed descriptively. The results found: 1) the average score of the validity test of the Guided Inquiry-based Natural Sciences practicum assessment instrument and the worksheets respectively were 3.45 and 3.62 . The validity results obtained stated that the overall assessment instruments included in the criteria are very valid. 2) the average score of the instrument readability test was 4.68 with very clear / easy to understand criteria. Based on the results of the validity test and the readability test, it can be concluded that the assessment instrument of guided inquirybased Natural Sciences is valid and legible.
\end{abstract}

Keywords : assessment instrument, science practicum, guided inquiry 


\section{PENDAHULUAN}

Salah satu komponen penting dalam penyelenggaraan pendidikan adalah penilaian atau asesmen. Uno dan Koni (2014) menyatakan bahwa penilaian adalah proses pemberian makna atau ketetapan kualitas hasil pengukuran dengan cara membandingkan angka hasil pengukuran tersebut dengan kriteria tertentu. Ketercapaian tujuan pembelajaran dapat diketahui melalui kegiatan penilaian yang mampu memberikan informasi mengenai kemampuan siswa yang terbagi ke dalam aspek kognitif, afektif, dan psikomotor. Permendikbud No. 66 Tahun 2013 tentang Standar Penilaian Pendidikan (2013: 3) menetapkan bahwa "penilaian hasil belajar peserta didik mencakup kompetensi sikap, pengetahuan, dan keterampilan yang dilakukan secara seimbang". Kompetensi keterampilan merupakan salah satu ranah kompetensi yang difokuskan pengembangannya pada Kurikulum 2013 melalui pendekatan ilmiah. Untuk mengetahui sejauh mana tingkat penguasaan siswa pada kompetensi keterampilan, maka diperlukan sistem penilaian yang tepat. Salah satu penilaian yang banyak digunakan dalam menentukan kemampuan seseorang adalah penilaian kinerja.

Penilaian kinerja adalah penilaian yang dilakukan dengan mengamati kegiatan peserta didik dalam melakukan sesuatu (Sudaryono, 2009). Sementara Berk (dalam Rasyid dan Mansur, 2009) menyatakan bahwa penilaian kinerja adalah proses mengumpulkan data dengan cara pengamatan yang sistematik untuk membuat keputusan tentang individu. Pelaksanaan penilaian kinerja dilakukan melalui proses pembelajaran yang menunjukkan kemampuan atau kinerja siswa dalam bentuk proses maupun produk (Zainul, 2001). Penilaian kinerja proses dan produk dapat dilakukan melalui pengamatan langsung terhadap kinerja yang ditunjukkan siswa selama kegiatan praktikum mulai dari tahap persiapan praktikum hingga pasca praktikum. Pada penilaian kinerja, guru harus menetapkan standar kerja yang akan diamati secara spesifik. Standar kerja inilah yang akan dijadikan sebagai indikator penilaian kualitas kinerja yang ditunjukkan siswa dalam praktikum.

Fakta menunjukkan bahwa instrumen penilaian praktikum IPA sampai saat ini belum ada yang baku. Belum ada instrumen penilaian yang telah berstandar, umumnya setiap sekolah dengan sekolah yang lain berbeda penilaiannya dan biasanya diserahkan kepada guru IPA masing-masing dan hanya dibuat dengan seadanya (Rahman, 2017). Hasil temuan Saputra (2014) menunjukkan bahwa penilaian kompetensi keterampilan dalam praktikum Biologi hanya dilakukan melalui pemberian tes tertulis dan penyelesaian tugas-tugas yang terdapat pada LKS, serta tidak disertai bukti autentik dari kinerja yang ditunjukkan siswa selama proses praktikum. Hal ini kurang sesuai dengan standar penilaian kompetensi keterampilan siswa, sebagaimana yang tertuang pada Permendikbud No. 66 Tahun 2013 yaitu penilaian kompetensi keterampilan harus menuntut siswa dalam mendemonstrasikan suatu kompetensi tertentu dengan menggunakan tes praktik (Permendikbud, 2013).

Permasalahan serupa juga terjadi di salah satu sekolah percontohan penerapan Kurikulum 2013 yaitu SMP Negeri 2 Singaraja. Pada tahap analisis kebutuhan (need assessment) yang dilakukan melalui wawancara tiga guru SMP di wilayah Singaraja didapat bahwa penilaian yang dilakukan dalam kegiatan pembelajaran dengan metode praktikum merupakan penilaian kelompok dengan cara mengamati kinerja kelompok selama praktikum. Penilaian kelompok dilakukan karena banyaknya siswa dalam kelas. Keterbatasan guru dalam mengamati siswa dengan jumlah besar menyebabkan guru mengandalkan ingatannya untuk mengingat kinerja siswa dalam melakukan praktikum. Hal ini sejalan dengan temuan Suastra dan Ristiati (2016) bahwa salah satu permasalahan guru dalam mengimplementasikan penilaian autentik dalam pembelajaran sains adalah karena banyaknya jumlah siswa dalam satu kelas (kelas gemuk yang siswanya $>30$ orang). Selain itu, karena keterbatasan waktu dalam melakukan penilaian yang meliputi 
penilaian afektif, kognitif, dan psikomotor secara bersamaan. Penilaian yang begitu kompleks inilah yang mengakibatkan guru hanya memfokuskan bagaimana siswa dalam menyajikan hasil diskusi bersama kelompok tanpa menilai keterampilan praktikum siswa dari tahap persiapan hingga pelaksanaan praktikum.

Berdasarkan hasil analisis instrumen penilaian praktikum IPA yang digunakan guru di salah satu sekolah melakukan wawancara didapatkan bahwa: (1) aspek penilaian pada instrumen penilaian praktikum masih secara umum dan tidak mendetail yang meliputi aspek merangkai alat, pengamatan, data yang diperoleh, dan kesimpulan. Aspek penilaian pada instrumen tersebut hanya dapat digunakan pada praktikum yang menuntut siswa dalam merangkai alat saja dan tidak dapat digunakan pada praktikum lainnya. (2) instrumen penilaian sudah dilengkapi dengan rubrik penilaian namun deskripsi kinerja/deskriptor kurang jelas sebagai acuan penilaian. Deskripsi pada setiap skor harus jelas dan berdasarkan pada keterangan kriteria, hal ini perlu dilakukan agar rubrik yang dikembangkan benarbenar valid (Abidin dalam Munandar et al., 2019). (3) penentuan skor pada instrumen penilaian yang digunakan menggunakan rentang skala pendek yaitu 1-3. Penentuan rentang skor pada instrumen penilaian harus secermat mungkin, karena semakin pendek skala yang digunakan maka akan semakin sulit mengidentifikasi perbedaan antar kinerja di tiap-tiap skor (Zainul, 2001). Rubrik yang digunakan untuk penilaian seharusnya memiliki beberapa kriteria agar penilaian dapat dilakukan secara valid, objektif, dan adil. Beberapa kriteria tersebut yaitu: 1) memuat seperangkat indikator untuk menilai kompetensi tertentu, 2) indikator diurutkan berdasarkan urutan langkah kerja pada tugas atau sistematika pada hasil kerja peserta didik, 3) dapat mengukur kemampuan yang akan diukur (valid), 4) dapat digunakan (feasible) dalam menilai kemampuan peserta didik, 5) dapat memetakan kemampuan peserta didik, 6) disertai dengan penskoran yang jelas untuk pengambilan keputusan (Abdullah, 2016).

Melihat pada permasalahan yang dihadapi guru dalam melakukan penilaian dan instrumen penilaian praktikum yang digunakan, maka dari itu diperlukan seperangkat instrumen penilaian kinerja pada praktikum IPA yang sesuai dengan standar penilaian kompetensi keterampilan baik dari segi substansi (isi), konstruksi, dan penggunaan bahasa. Beberapa penelitian yang dilakukan untuk mengetahui penggunaan instrumen penilaian praktikum dalam menilai kemampuan aspek psikomotor siswa, diantaranya penelitian yang dilakukan oleh Sarjono et al., 2018 menunjukkan hasil bahwa konstruk instrumen yang dikembangkan terdiri dari empat aspek, yaitu: 1) persiapan praktikum, 2) pelaksanaan praktikum, 3) hasil praktikum, dan 4) pelaporan. Instrumen tersebut menunjukkan kevalidan, dapat diandalkan, dan cocok untuk diterapkan pada peserta didik yang memiliki kemampuan menengah. Penelitian yang dilakukan oleh Budhiwaluyo et al., 2016 menunjukkan hasil instrumen penilaian kinerja dinyatakan cukup baik dan layak digunakan untuk mengukur dan menilai kinerja siswa baik aspek proses maupun produk pada praktikum struktur dan fungsi sel. Kedua penelitian tersebut menunjukkan bahwa penggunaan instrumen penilaian praktikum IPA secara valid dan objektif, berpengaruh positif terhadap faktor-faktor pendorong kegiatan belajar lainnya seperti minat dan motivasi belajar.

Mengingat belum semua instrumen penilaian praktikum IPA yang digunakan dapat mengukur target kemampuan yang akan diukur (valid), dan perlunya aspek penilaian pada instrumen penilaian praktikum IPA harus mendetail, serta deskriptor pada instrumen penilaian harus jelas dan berdasarkan pada ketercapaian kriteria, maka perlu dilakukan penelitian dan pengembangan terhadap instrumen penilaian praktikum IPA berbasis inkuiri terbimbing.

Pemilihan model inkuiri terbimbing ini karena model inkuiri terbimbing adalah salah satu model yang dianjurkan dalam pendekatan saintifik dan model pembelajaran inkuiri dilandasi oleh prinsip learning by doing. Permendikbud No. 21 Tahun 2016 tentang Standar Isi menjelaskan bahwa pembelajaran IPA di SMP/MTs sebaiknya dilaksanakan secara 
inkuiri ilmiah (scientific inquiry) yang sudah tertuang pada kompetensi muatan IImu Pengetahuan Alam dengan tujuan dapat menumbuhkan kemampuan berpikir dan menunjukkan sikap ilmiah yang meliputi rasa ingin tahu, jujur, logis, kritis, dan disiplin. Dilihat dari hal tersebut, karakteristik pembelajaran IPA tingkat SMP/MTs selalu menekankan pada pemberian pengalaman belajar secara inkuiri.

Sund (dalam Sadia, 2014) menyatakan bahwa penerapan model pembelajaran inkuiri dalam pembelajaran sains memberikan beberapa keuntungan, salah satu keuntungannya adalah proses pembelajaran menjadi berpusat pada siswa (student center). Melalui model pembelajaran inkuiri, para siswa akan terlibat secara aktif baik fisik maupun mental dalam proses pembelajaran, sedangkan guru lebih banyak berperan sebagai fasilitator dan mediator. Berdasarkan latar belakang masalah yang telah peneliti uraikan, maka peneliti tertarik untuk melakukan penelitian dengan judul "Pengembangan Instrumen Penilaian Praktikum IPA Berbasis Inkuiri Terbimbing".

\section{METODE}

Penelitian ini menggunakan metode penelitian dan pengembangan (Research and Development) dengan model 4D yaitu Define, Design, Develop, dan Disseminate. Penelitian ini dibatasi sampai tahap develop. Tahap define terbagi menjadi lima langkah kegiatan yaitu analisis ujung depan, analisis siswa, analisis konsep, analisis tugas, dan perumusan tujuan pembelajaran. Tahap define bertujuan untuk menetapkan dan mendefinisikan syarat-syarat instrumen penilaian sebelum dikembangkan. Tahap design dilakukan untuk merancang instrumen penilaian dengan mengikuti empat langkah yaitu penyusunan tes acuan patokan, pemilihan media, pemilihan format, dan rancangan awal. Pada tahap ini akan dihasilkannya draf instrumen penilaian. Tahap develop adalah tahap untuk menghasilkan produk yang valid dan terbaca melalui uji validitas dan uji keterbacaan.

Data yang diperlukan dalam penelitian ini adalah data kualitatif dan kuantitatif. Data kualitatif didapat dari saran dan masukan ahli dan guru. Data kuantitatif didapat melalui hasil angket validasi dan angket uji keterbacaan. Teknik analisis data yang digunakan adalah teknik perhitungan rata-rata yang dikemukakan oleh Arikunto (2006).

\section{HASIL DAN PEMBAHASAN Tahap Define}

Pada tahap ini dilakukan lima langkah analisis untuk menetapkan masalah dasar kriteria-kriteria yang digunakan sebagai acuan dalam mengembangkan instrumen penilaian praktikum IPA berbasis inkuiri terbimbing.

\section{Analisis Ujung Depan}

Analisis ujung depan dilakukan dengan mewawancarai tiga guru IPA SMP di wilayah Singaraja. Hasil wawancara menunjukkan bahwa penilaian keterampilan dalam kegiatan praktikum dilakukan secara berkelompok dan instrumen penilaian yang menilai aspek keterampilan siswa tidak mendetail. Penilaian aspek keterampilan dalam kegiatan praktikum yang dilakukan dalam bentuk penilaian kelompok tidak sesuai dengan esensi belajar sebagai tindakan dan perilaku siswa yang kompleks yang hanya dialami oleh siswa sendiri (Dimyati dan Mudjiono, 2009).

Berdasarkan hasil analisis instrumen penilaian yang digunakan diketahui bahwa instrumen penilaian yang digunakan sudah dilengkapi dengan rubrik namun deskriptor pada rubrik kurang jelas sebagai acuan penilaian. Karena penilaian praktikum merupakan penilaian yang dilakukan secara subjektif berdasarkan pengamatan guru, maka diperlukan acuan yang jelas untuk menilai kemampuan praktikum. Penggunaan rubrik juga dapat menjamin reliabilitas, keadilan, dan kebenaran (Zainul, 2001). Adapun materi yang dipilih sebagai materi pengembangan instrumen didapat dari hasil wawancara guru yang menyatakan bahwa salah satu materi yang sering dipraktikkumkan adalah getaran dan gelombang.

\section{Analisis Siswa \\ Hasil analisis siswa melalui kajian literatur menunjukkan bahwa}


perkembangan kognitif siswa SMP termasuk ke dalam tahap operasional formal menurut teori belajar Piaget. Pada tahap operasional formal, siswa sudah memiliki dua ragam kemampuan kognitif yaitu kapasitas menggunakan hipotesis dan kapasitas menggunakan prinsip-prinsip abstrak (Syah, 2013).

Berdasarkan hasil wawancara terhadap tiga siswa SMP kelas VIII memberikan informasi mengenai pengalaman mereka saat kegiatan praktikum, dimana dalam kegiatan praktikum yang mereka lakukan terbagi menjadi tahap persiapan, pelaksanaan, dan penutup.

\section{Analisis Konsep}

Tahap analisis konsep terbagi menjadi dua yakni analisis materi dan analisis $\mathrm{KI}$ dan KD. Berdasarkan hasil analisis ujung depan, didapatkan materi getaran dan gelombang sebagai materi yang akan dikembangkan dalam instrumen penilaian. Materi getaran dan gelombang dianalisis dan hasilnya digambarkan dalam bentuk peta konsep. Martin (dalam Trianto, 2009) menyatakan bahwa peta konsep adalah ilustrasi grafis konkret yang mengindikasikan bagaimana sebuah konsep tunggal dihubungkan ke konsepkonsep lain pada kategori yang sama. Submateri yang dipilih pada peta konsep adalah getaran, gelombang, dan bunyi. Setelah didapatkan submateri, selanjutnya dilakukan analisis $\mathrm{KI}$ dan $\mathrm{KD}$ tersebut ke dalam indikator pembelajaran. Sesuai dengan submateri dan aspek kemampuan yang akan dinilai, maka indikator pembelajaran yang dipilih adalah berdasarkan pada KD 4.11 menyajikan percobaan tentang getaran, gelombang, dan bunyi untuk menjadi acuan pada tahap selanjutnya yaitu tahap analisis tugas.

\section{Analisis Tugas}

Hasil kajian literatur pada tahap analisis tugas, didapatkan keterampilan psikomotor siswa saat kegiatan praktikum mencakup keterampilan manipulatif dalam menggunakan alat-alat laboratorium dan keterampilan prosedural dalam melakukan pekerjaan dengan urutan tertentu. Sofyan et al., 2006 menjelaskan bahwa keterampilan manipulatif adalah keterampilan menggunakan alat-alat laboratorium dan keterampilan prosedural adalah keterampilan melakukan perangkat pekerjaan dengan urutan tertentu.

Trowbridge dan Bybee (1980), mengidentifikasi aktivitas yang dilakukan siswa dalam kegiatan praktikum, diantaranya menyediakan alat, mepersiapkan alat dan bahan, membaca instrumen, mengkalibrasi alat, menganalisis data, menyimpulkan data hasil praktikum, menulis laporan praktikum, dan membersihkan dan menyimpan alat yang telah digunakan. Keterampilan tersebut kemudian diuraikan ke dalam bentuk aktivitas siswa berupa keterampilan psikomotor kemudian aktivitas tersebut dikelompokkan berdasarkan pembagian kegiatan praktikum

\section{Perumusan Tujuan Pembelajaran}

Sesuai dengan submateri dan aspek kemampuan yang akan dinilai, maka indikator pembelajaran pada KD 4.11 yang akan dipilih menjadi acuan dalam menentukan perumusan tujuan pembelajaran. Tujuan instruksional pada dasarnya adalah rumusan tentang bentukbentuk tingkah laku yang akan dimiliki siswa setelah mengikuti proses pembelajaran (Hakiim, 2009). Perumusan tujuan pembelajaran terdiri dari hasil analisis konsep, hasil analisis tugas dan tujuan pembelajaran. Perumusan tujuan pembelajaran ini kemudian menjadi dasar dalam menyusun kisi-kisi instrumen penilaian.

\section{Tahap Design}

Pada tahap design dilakukan penyusunan perangkat dan komponen penunjang instrumen penilaian. Tahap ini terdiri dari empat langkah yakni penyusunan tes acuan patokan, pemilihan media, pemilihan format, dan rancangan awal.

\section{Penyusunan Tes Acuan Patokan}

Pada langkah penyusunan tes acuan patokan dihasilkannya kisi-kisi instrumen penilaian yang disusun berdasarkan rumusan tujuan pembelajaran. Tes acuan patokan adalah tes yang digunakan untuk mengukur penguasaan atau kemampuan 
siswa melalui kriteria tertentu yang telah ditetapkan sebelumnya (Sukardi, 2012).

Pada pengembangan instrumen penilaian, pengukuran kemampuan siswa didapat dari aspek penilaian yang dimuat dalam instrumen penilaian. Kisi-kisi instrumen penilaian terdiri dari:

1. $\mathrm{KI}, \mathrm{KD}$, indikator, dan tujuan pembelajaran pada submateri getaran dan gelombang.

2. Kolom kegiatan yang dinilai dalam praktikum memuat pembagian penilaian dalam kegiatan praktikum yang meliputi tahap persiapan praktikum, tahap pelaksanaan praktikum, tahap kegiatan akhir praktikum, dan tahap pelaporan.

3. Kolom fase inkuiri terbimbing memuat fase-fase inkuiri terbimbing yang meliputi merumuskan masalah, merumuskan hipotesis, merancang dan melakukan eksperimen, mengumpulkan dan mengolah data, interpretasi hasil analisis data dan pembahasan, dan membuat kesimpulan. Fase-fase inkuiri terbimbing ini akan menjadi aspek yang dinilai pada tahap pelaksanaan praktikum.

4. Kolom aspek yang dinilai memuat indikator penilaian pada kegiatan yang dinilai dalam praktikum.

5. Kolom kriteria yang dinilai memuat rubrik pada semua aspek yang dinilai. Rentang skor pada rubrik yaitu 1-4.

6. Kolom jumlah butir menunjukkan kuantitas butir penilaian.

\section{Pemilihan Media}

Setelah didapatkan kisi-kisi

instrumen penilaian, kemudian dilakukan tahap pemilihan media. Media yang dipilih yakni lembar kerja praktikum dan alat dan bahan yang digunakan. Lembar kerja praktikum dipilih karena memuat soal atau perintah kerja yang menuntut siswa untuk memunculkan kemampuan dalam bentuk tindakan nyata. Penggunaan lembar kerja praktikum juga dapat membimbing dan mengarahkan siswa ketika melakukan kegiatan praktikum tanpa banyak didominasi oleh instruksi guru (Prastowo, 2011). Isi dalam lembar kerja praktikum terdiri atas judul praktikum, tujuan, dasar teori, fenomena, prosedur kerja, tabel/hasil pengamatan, diskusi, dan kesimpulan. Alat dan bahan yang digunakan juga merupakan komponen penunjang kegiatan praktikum yang ditampilkan pada Tabel 1.

Tabel 1

Alat dan Bahan Praktikum

\begin{tabular}{lc}
\hline Alat dan Bahan & Jumlah \\
\hline Bandul & 1 buah \\
Statif & 1 buah \\
Stopwatch & 1 buah \\
Penggaris & 1 buah \\
Tali nilon & $50 \mathrm{~cm}$ \\
Tali tambang & 1 meter \\
Slinki & 1 buah \\
Gitar & 1 buah \\
Garpu tala dan pemukul garpu & 1 buah \\
tala & \\
\hline
\end{tabular}

Pemilihan Format

Pemilihan format berfungsi untuk mengatur tampilan instrumen penilaian. Pada tahap ini dihasilkannya format instrumen penilaian yang terbagi menjadi empat aspek yang dinilai yaitu kegiatan persiapan praktikum, pelaksanaan praktikum, kegiatan akhir praktikum, dan pelaporan. Instrumen penilaian yang dikembangkan terbagi menjadi dua yaitu aspek penilaian dalam bentuk lembar observasi dan lembar gradasi mutu (rubrik) yang memuat skor dan deskriptor.

Lembar observasi memuat kegiatan yang dinilai dalam praktikum yang meliputi empat tahap praktikum, aspek penilaian pada tiap-tiap kegiatan praktikum, dan kolom untuk skor yang diberikan. Sementara kolom penilaian berisi rentang skor dari 1-4. Format lembar gradasi mutu (rubrik) memuat skor dengan rentang 1-4 dan berisikan deskriptor pada tiap rentang skor.

Penentuan kinerja yang dinilai diawali dengan mencermati soal atau perintah kerja yang dimuat pada lembar kerja praktikum, kemudian mengidentifikasi aspek-aspek keterampilan kunci. Keterampilan kunci kemudian dirumuskan dalam bentuk kalimat pernyataan yang didefinisikan secara jelas. Penyusunan aspek penilaian pada instrumen berdasarkan pada urutan soal atau perintah kerja yang terdpat pada lembar kerja praktikum. 
Aspek penilaian yang telah ditetapkan kemudian ditentukan kualitasnya menggunakan mutu penilaian atau yang disebut dengan rubrik. Rasyid dan Mansur (2009) menyatakan bahwa rubrik merupakan daftar kriteria yang diwujudkan dengan aspek-aspek kinerja yang akan dinilai beserta gradasi mutu dari yang paling sempurna hingga yang paling tidak sempurna. Rentang skor yang digunakan adalah 1-4. Penentuan rentang skor didasarkan pada jumlah keterampilan yang didapat ditiap kegiatan praktikum. Selain itu, penentuan skor juga berdasarkan pada kemampuan peneliti dalam membedakan deskripsi kerja pada tiap tingkatan skor. Penentuan rentang skor secermat mungkin, karena semakin panjang skala yang digunakan maka semakin sulit tercapainya kesepakatan antar penilai, sedangkan skala pendek juga berakibat sulitnya mengidentifikasi perbedaan yang kecil antar kinerja (Zainul, 2001).

Penentuan deskriptor ditiap tingkatan skor didapat dari hasil identifikasi aspek keterampilan pada tiap aspek penilaian. Deskriptor tersebut kemudian diurutkan dari kinerja terbaik hingga kinerja terburuk berdasarkan aturan pada Permendikbud No. 81A Tahun 2013. Jumlah tingkatan kualitas deskriptor disesuaikan dengan panjang skala yang telah ditetapkan sebelumnya, dimana kualitas kinerja terbaik dinyatakan dengan skor tertinggi dan kualitas terburuk dinyatakan dengan skor terendah.

\section{Rancangan Awal}

Dari pemilihan media dan format yang telah ditetapkan, selanjutnya dilakukan penyusunan lembar kerja praktikum dan instrumen penilaian. Desain awal produk draf I berupa kisi-kisi instrumen beserta rubriknya dan LKS. Revisi selama proses penyusunan dilakukan atas arahan dosen pembimbing guna memperbaiki kualitas produk yang dikembangkan. Revisi pada desain awal diantaranya yaitu tinjau kembali aspek-aspek penilaian pada instrumen yang berkaitan dengan fase-fase inkuiri dan tujuan pada LKS tidak perlu dicantumkan tujuan pembelajaran pada KD 3.
Hasil revisi dari draf produk I selanjutnya menghasilkan draf produk II. Draf produk II kemudian kembali dibimbingkan dan mendapat masukan yaitu mengenai rubrik pada lembar observasi dipisahkan dan tambahkan format pembuatan laporan. Hasil revisi dari draf produk II selanjutnya menghasilkan draf produk III, produk ini sudah mengalami penyempurnaan dan sudah dianggap layak untuk dilanjutkan ke uji ahli.

Pada tahap perancangan ini juga dilakukan penyusunan angket uji validitas dan angket uji keterbacaan. Angket uji validitas memuat aspek penilaian instrumen penilaian praktikum IPA berbasis inkuiri terbimbing LKS dan meliputi desain/tampilan, konstruksi, materi, rubrik, dan bahasa. Angket uji keterbacaan memuat bagaimana respon pengguna sebelum menggunakan produk yang dikembangkan. Angket-angket ini kemudian dibimbingkan kepada dosen pembimbing dan mendapat masukan terkait pernyataan-pernyataan pada angket uji keterbacaan. Hasil revisi dari angket tersebut kemudian dilanjutkan ke tahap validitas dan uji keterbacaan.

\section{Tahap Develop}

Pada tahap pengembangan dihasilkan instrumen penilaian yang sudah direvisi berdasarkan saran dari validator untuk kemudian digunakan pada tahap uji keterbacaan. Tahap pengembangan terbagi menjadi dua tahap yaitu tahap validitas dan uji keterbacaan.

\section{Hasil Uji Validasi}

Kevalidan dari instrumen penilaian praktikum IPA berbasis inkuiri terbimbing diperoleh melalui penilaian dua pakar (ahli) pada lembar validasi tiap instrumen yang telah dikembangkan. Dua ahli yang dilibatkan untuk melakukan review produk yang dikembangkan adalah dosen berjenjang S3 di Prodi S1 Pendidikan IPA Universitas Pendidikan Ganesha.

Tujuan penilaian ahli terhadap produk yang dikembangkan adalah untuk mengkaji ketepatan desain/tampilan, materi, konstruksi, dan bahasa terhadap LKS dan mengkaji ketepatan rubrik terhadap instrumen penilaian praktikum IPA berbasis 
inkuiri terbimbing yang dikembangkan. Pada tahap validitas didapatkan data kuantitatif hasil validasi dan data kualitatif berupa saran atau komentar terhadap produk yang dikembangkan. Hasil analisis data validasi oleh ahli dapat dilihat pada Tabel 2 dan Tabel 3.

\section{Tabel 2 \\ Hasil Validasi Instrumen Penilaian Praktikum IPA Berbasis Inkuiri Terbimbing}

\begin{tabular}{cll}
\hline No & Aspek Validasi & Rata-rata \\
\hline 1 & $\begin{array}{l}\text { Petunjuk penggunaan instrumen penilaian praktikum IPA } \\
\text { berbasis inkuiri terbimbing jelas dan mudah dipahami }\end{array}$ & 3,5 \\
2 & $\begin{array}{l}\text { Pedoman penskoran dalam instrumen penilaian praktikum IPA } \\
\text { berbasis inkuiri terbimbing jelas dan mudah dipahami }\end{array}$ & 3,5 \\
3 & $\begin{array}{l}\text { Urutan penilaian pada instrumen penilaian berurutan sesuai } \\
\text { dengan prosedur praktikum yang dilaksanakan }\end{array}$ & 4 \\
4 & $\begin{array}{l}\text { Deskriptor pada setiap skor jelas dan berdasarkan pada } \\
\text { ketercapaian kriteria yang dinilai }\end{array}$ & 3 \\
5 & $\begin{array}{l}\text { Deskriptor pada setiap skor sudah berurutan sesuai tingkatan } \\
\text { kualitas kinerja terbaik hingga kualitas terburuk }\end{array}$ & 3,5 \\
6 & $\begin{array}{l}\text { Deskriptor pada instrumen penilaian mampu membedakan } \\
\text { keterampilan psikomotorik siswa }\end{array}$ & 3,5 \\
7 & $\begin{array}{l}\text { Bahasa yang digunakan pada instrumen penilaian mudah } \\
\text { dipahami dan dimengerti }\end{array}$ & 3 \\
8 & $\begin{array}{l}\text { Kalimat yang digunakan pada instrumen penilaian efektif dan } \\
\text { menggunakan bahasa Indonesia yang baku/EBI (Ejaan Bahasa } \\
\text { Indonesia) }\end{array}$ & 3,5 \\
9 & $\begin{array}{l}\text { Instrumen penilaian praktikum IPA berbasis inkuiri terbimbing } \\
\text { mudah digunakan }\end{array}$ & 3 \\
10 & $\begin{array}{l}\text { Instrumen penilaian praktikum IPA berbasis inkuiri terbimbing } \\
\text { mudah diadministrasikan }\end{array}$ & 4 \\
Rata-rata & $\mathbf{3 , 4 5}$ \\
\hline
\end{tabular}

Tabel 3

Hasil Validasi LKS

\begin{tabular}{|c|c|c|c|}
\hline \multirow[t]{2}{*}{ No } & \multirow[t]{2}{*}{ Aspek Validasi } & \multicolumn{2}{|c|}{$\begin{array}{c}\text { Rata-rataSkor } \\
\text { dari Ahli }\end{array}$} \\
\hline & & 1 & 2 \\
\hline 1 & Desain/tampilan (terdiri dari 5 indikator) & 3,8 & 3,2 \\
\hline 2 & Materi (terdiri dari 4 indikator) & 3,75 & 3,5 \\
\hline 3 & Konstruksi (terdiri dari 4 indikator) & 4 & 3,25 \\
\hline 4 & Bahasa (terdiri dari 4 indikator) & 4 & 3,5 \\
\hline & Rata-rata skor & 3,88 & 3,35 \\
\hline & Rata-rata validitas & & 62 \\
\hline
\end{tabular}

Berdasarkan Tabel 2, hasil validasi instrumen penilaian praktikum IPA berbasis inkuiri terbimbing adalah 3,45 dan validasi LKS adalah 3,62. Hasil validasi produk yang diperoleh secara keseluruhan menyatakan bahwa instrumen penilaian praktikum IPA berbasis inkuiri terbimbing termasuk dalam kriteria sangat valid. Selain hasil validasi, validator memberikan masukan dan saran untuk menyempurnakan instrumen penilaian praktikum IPA yang dikembangkan. Masukan dan saran tersebut kemudian dijadikan acuan peneliti untuk melakukan 
revisi produk yang dikembangkan. Hasil penelitian tersebut sejalan dengan penelitian yang dilakukan Yuniarti (2014) yang menunjukkan bahwa hasil rata-rata skor validasi ahli sebesar 3,31 dan masuk kriteria sangat valid dan layak digunakan sebagai instrumen penilaian dengan sedikit revisi.

Hasil validasi ahli menunjukkan bahwa instrumen penilaian sudah sesuai dari aspek desain/tampilan, materi, konstruksi, rubrik, dan bahasa. Hal tersebut berarti: 1) dari segi aspek desain/tampilan, instrumen penilaian sudah sesuai dengan desain yang meliputi tampilan cover instrumen dan perpaduan warna. 2) dari segi aspek materi, menunjukkan bahwa instrumen penilaian sudah sesuai dengan tujuan pembelajaran. 3) dari segi aspek konstruksi, menunjukkan bahwa instrumen penilaian telah memenuhi validitas konstruksi dimana butir-butir pada instrumen penilaian yang membangun instrumen dapat mengukur dengan tepat aspek-aspek keterampilan pada kegiatan praktikum. 4) dari segi rubrik, deskriptor pada instrumen penilaian sudah jelas dan sesuai dengan tingkatan kualitas kinerja disetiap skor. 5) dari segi aspek bahasa, menunjukkan bahwa penggunaan bahasa sudah sesuai dengan bahasa Indonesia yang baik dan benar menurut Ejaan Bahasa Indonesia (EBI) dan bersifat ringkas dan jelas (Ekawati \& Sumaryanta, 2011).

Meskipun instrumen penilaian yang dikembangkan sudah masuk dalam kategori sangat valid digunakan sebagai instrumen penilaian, namun ada beberapa saran dan masukan dari ahli untuk menyempurnakan instrumen penilaian praktikum IPA yang dikembangkan. Saran yang paling banyak diberikan diantaranya mengenai tata bahasa dan tata tulis. Tata cara penulisan banyak yang tidak tepat misalnya penggabungan kata dan pemisahan kata atau kalimat. Sedangkan dari segi tata bahasa, banyak kata yang belum menggunakan bahasa baku yang sesuai dengan Ejaan Bahasa Indonesia (EBI) dan mengubah gaya bahasa yang digunakan pada aspek instrumen penilaian agar kalimat tidak berbelit-belit.

\section{Uji Keterbacaan}

Instrumen penilaian yang sudah direvisi sesuai masukan dari validator selanjutnya akan diuji keterbacaannya. Uji keterbacaan dilakukan dengan melibatkan tiga guru IPA di SMP Negeri 2 Singaraja untuk menguji keterbacaan instrumen penilaian yang dikembangkan sebelum digunakan. Dari 15 indikator pada angket uji keterbacaan oleh tiga guru, skor rata-rata hasil keterbacaan adalah 4,68 dengan kriteria sangat paham/sangat jelas. Keterbacaan instrumen penilaian yang dikembangkan ini sangat jelas dan mudah dipahami oleh guru. Hal ini disebabkan karena instrumen penilaian praktikum IPA memiliki petunjuk penggunaan yang jelas, pedoman penskoran jelas, rubrik penilaian jelas dan kalimat yang digunakan pada instrumen penilaian tidak menimbulkan penafsiran ganda.

\section{SIMPULAN DAN SARAN}

Berdasarkan hasil penelitian pengembangan instrumen penilaian praktikum IPA berbasis inkuiri terbimbing, maka dapat ditarik kesimpulan sebagai berikut.

Pertama, prosedur pengembangan instrumen penilaian praktikum IPA berbasis inkuiri terbimbing menggunakan model 4D yang terdiri dari tahap define, design, dan develop. Penelitian ini dibatasi sampai tahap develop. Dengan mengikuti prosedur tersebut, maka dihasilkannya produk yang valid dan terbaca.

Kedua, hasil skor rata-rata validitas terhadap instrumen penilaian praktikum berbasis inkuiri terbimbing LKS dan secara berturut-turut sebesar 3,45 dan 3,62 . Berdasarkan hasil validitas produk secara keseluruhan menyatakan bahwa instrumen penilaian praktikum IPA berbasis inkuiri terbimbing termasuk dalam kriteria sangat valid.

Ketiga, hasil uji keterbacaan oleh tiga guru IPA diperoleh skor rata-rata sebesar 4,68 dengan kriteria sangat jelas/mudah dipahami.

Sebagai tindak lanjut dari hasil penelitian ini, maka dikemukakan beberapa saran yaitu penelitian hendaknya dilakukan sampai pada tahap disseminate atau uji coba secara luas untuk mengetahui 
efektivitas penggunaan instrumen penilaian dalam kegiatan pembelajaran. Uji coba hendaknya dilakukan di beberapa sekolah sehingga dapat diketahui keterbacaan instrumen yang dikembangkan pada kondisi sekolah dan karakteristik siswa yang berbeda. Serta perlu dikembangkannya instrumen penilaian praktikum lainnya pada materi IPA yang berbeda. Hal ini dikarenakan aspek-aspek penilaian praktikum antara materi praktikum satu dengan materi praktikum lainnya tidak dapat disamakan.

\section{DAFTAR PUSTAKA}

Abdullah, R. S. 2016. Penilaian Autentik. Jakarta: Bumi Aksara.

Aprilia, N., Much, F., S., Nugroho, A., W., \& Jumi, S. 2017. Pengembangan Instrumen Penilaian Psikomotor Siswa SMA pada Praktikum Materi Protista. Seminar Nasional Pendidikan Sains, 46-53. Universitas Sebelas Maret: Surakarta.

Arikunto, S. 2006. Prosedur Penelitian Suatu Pendekatan Praktik Edisi Revisi IV. Jakarta: Rineka Cipta.

Budhiwaluyo, N., Rayandra, A., \& Bambang, H. 2016.

Pengembangan Instrumen

Penilaian Kinerja pada Praktikum Struktur dan Fungsi Sel di SMA Negeri 1 Kota Jambi. Jurnal Edu- Sains, 5(2),17. Universitas Jambi: Jambi.

Dimyati \& Mudjiono. 2009. Belajar dan pembelajaran. Jakarta: Rineka Cipta.

Ekawati, E.\& Sumaryanta. 2011. Pengembangan Instrumen Penilaian Matematika SD/SMP. Jakarta: Kementerian Pendidikan Nasional.

Hakiim, L. 2009. Perencanaan Pembelajaran. Bandung: CV Wacana Prima.

Munandar, A., Maryani, E., Rohmat, D., \& Ruhimat, M. 2019. Fieldstudy Dalam Geografi. Sidoarjo: Uwais Inspirasi Indonesia. Online.

Peraturan Menteri Pendidikan dan Kebudayaan Republik Indonesia No. 81A Tahun 2013 tentang
Implementasi Kurikulum, 2013. Jakarta.

Peraturan Menteri Pendidikan dan Kebudayaan Republik Indonesia No. 66 Tahun 2013 tentang

Standar Penilaian, 2013. Jakarta.

Prastowo, A. 2011. Panduan Kreatif Membuat Bahan Ajar Inovatif. Yogyakarta: DIVA Press.

Rahman, A. H. 2017. Instrumen Penilaian Kinerja Praktikum IImu Pengetahuan Alam Fisika SMP Menggunakan Pendekatan Saintifik. Prosiding Seminar Nasional Pendidikan, 33-40. Universitas Sultan Ageng Tirtayasa: Banten.

Rasyid, H. \& Mansur. 2009. Penilaian Hasil Belajar. Bandung: CV Wacana Prima.

Saputra, D. A., Abdullah, A. G., \& Hakim, D. L. 2014. Pengembangan Model Evaluasi Pembelajaran Project Based Learning Berbasis Logika Fuzzy. INVOTEC, 10(1), 13-24. Universitas Pendidikan Indonesia: Bandung.

Sarjono, Mardapi, D., \& Mundilarto. 2018. Development of Physics Lab Assesment Instrument for Senior High School Level. International Journal of Instruction, 11(4), 17-28. Yogyakarta State University: Indonesia.

Sofyan, A., Feronika, T., \& Milama, B. 2006. Evaluasi Pembelajaran IPA

Berbasis Kompetensi. Jakarta: UIN Jakarta Press.

Syah, M. 2013. Psikologi Pendidikan. Bandung: Remaja Rosdakarya.

Suastra, I. W. \& Ristiati, N. P. 2016. Permasalahan Guru dalam Merancang dan

Mengimplementasikan Penilaian Otentik dalam Pembelajaran Sains di SMP dan SMA. Seminar Nasional Riset Inovatif (SENARI), 304-313. Universitas Pendidikan Ganesha: Singaraja.

Sudaryono. 2012. Dasar-dasar Evaluasi Pembelajaran. Yogyakarta: Graha IImu. 
Sukardi, H. M. 2012. Evaluasi Pendidikan:

Prinsip \& Operasionalnya. Jakarta: Bumi Aksara.

Thiagarajan, S., Sememel, D., \& Semmel M. I. $1974 . \quad$ Instructional Development for Training Teacher of Exceptional Children. Online. Indiana University: Bloomington, Indiana.

Trianto. 2009. Mendesain Model Pembelajaran Inovatif, Progresif, dan Kontekstual. Jakarta:

Prenadamedia Group.

Trowbridge, L \& Bybee, R. 1986. Becoming a Secondary School Science Teacher. Columbus: Merril.

Uno, H. B \& Koni, S. 2014. Assessment Pembelajaran. Jakarta: Bumi Aksara.

Yuniarti, B., Siska, D. F., \& Arif, M. 2014. Pengembanga Instrumen Penilaian Psikomotor pada Pelaksanaan Praktikum Fisika Siswa Kelas $X$ SMA Negeri 5 Purworejo Tahun Pelajaran 2013/2014. Radiasi, 5(1), 77-81. Universits Muhammadiyah: Purworejo.

Zainul, A. 2001. Alternative Assesment. Jakarta: PAU-PPAI Universitas Terbuka. 